\title{
O FUNK E A LEITURA DIALÓGICA DE SUJEITOS: A PERSPECTIVA BAKHTINIANA
}

\section{THE FUNK AND THE DIALOGICAL READING OF SUBJECTS: THE BAKHTINIAN PERSPECTIVE}

\section{Manuella Queiroz da Silva ${ }^{1}$ Maria da Penha Casado Alves ${ }^{2}$}

\begin{abstract}
Resumo: Neste estudo, realizado com alunos do $9^{\circ}$ ano do Ensino Fundamental, propomos uma busca do (re)conhecimento do sujeito social representado nas letras do funk que são utilizadas como instrumentos de reflexão em ambiente escolar, tendo como aporte teórico as concepções advindas do Círculo de Bakhtin. Para tanto, estruturamos tal pesquisa nas leituras do gênero discursivo canção do funk e nas atividades constantes no protótipo de ensino com base em Rojo (2015). Entendendo que a dialogicidade discursiva também se perfaz no ato da leitura, este estudo procura compreender o gênero discursivo literomusical funk, na tentativa de (re)conhecer as vozes existentes, bem como a responsividade dessas vozes, quais valores representam e o posicionamento dos alunos(as) quanto ao gênero discursivo em foco.
\end{abstract}

Palavras-chave: gênero discursivo; funk; leitura; dialogicidade; protótipo de ensino.

Abstract: In this study, developed out with 9th students of Elementary School, we propose a search for the (re) knowledge of the social subject represented in the funk letters that are used as reflection tools in a school environment, having as theoretical contribution the conceptions coming from the Circle of Bakhtin. To do so, we structured such research in the readings of the funk song discursive genre and in the constant activities in the Red-based (2015) prototype of teaching. Understanding that discursive dialogue also takes place in the act of reading, this study seeks to understand the literature and music in the funk discursive genre, in an attempt to (re) know the existing voices, as well as the responsiveness of these voices, which values represent and the positioning of the students as) to the discursive genre in focus.

Keywords: discursive genre; funk; reading; dialogicity; prototype of teaching.

\section{Introdução}

Expressar-se oralmente, pelo que se percebe nitidamente em sala de aula, está diretamente relacionado à leitura de mundo que cada aluno(a) traz consigo. Os alunos são conscientes de que sua voz tem poder, mas ainda não conseguem, em determinados ambientes, notadamente em sala de aula, exercitar essas vozes, pois, para isso, precisam atuar como sujeitos

\footnotetext{
${ }^{1}$ Mestre em Letras pelo ProfLetras na Universidade Federal do Rio Grande do Norte (UFRN). Docente da educação básica. Email: lellaq@hotmail.com

${ }^{2}$ Doutora em Comunicação e Semiótica pela Pontifícia Universidade Católica de São Paulo (PUC/SP), docente da Universidade Federal do Rio Grande do Norte (UFRN) e Coordenadora Nacional do Programa de Mestrado Profissional em Letras em Rede Nacional (ProfLetras). Email: penhalves@msn.com
} 
que respondem aos diferentes textos configurados nos mais diversos gêneros discursivos. Ler e assumir uma compreensão responsiva ativa diante do texto lido precisa ser exercício permanente em sala de aula e projeto a ser concretizado na escola.

No intuito de fomentar a reflexão a partir da leitura, elaboramos um protótipo de ensino, realizado com uma turma do $9^{\circ}$ ano (2016) do turno matutino de uma escola situada em Natal/RN, do gênero discursivo funk, cujas letras propiciam a troca de pontos de vista, possibilitando, assim, democratizar os saberes e compreender o mundo da vida. Para fins deste artigo, um recorte desse estudo será apresentado a seguir.

Este trabalho ${ }^{3}$ justifica-se pela necessidade de trabalhar a leitura a fim de formar leitores responsivos e críticos. Por consequência, espera-se estimular os sujeitos, no sentido de se tornarem mais atuantes socialmente, a fim de que possam vislumbrar na leitura um ato prazeroso e necessário, como sujeitos dotados de criticidade. Em nossa vivência docente, temos constatado que a falta de interesse pela leitura em sala de aula e a dificuldade dos alunos em redigir textos escolares é constante, mesmo reconhecendo que os nossos alunos leem e escrevem sim, mas sempre voltados aos temas do seu cotidiano mais imediato, seja por mensagens via SMS, seja pelo Whatsapp e diversas redes sociais, seja por uma necessidade de cunho mais informal e de maneira mais espontânea. Torna-se, então, um desafio para o professor de Ensino Fundamental estimular os seus alunos a se envolverem no ato de ler em ambiente escolar, mais especificamente.

Em suma, a escolha de se trabalhar o gênero funk em sala de aula com o público juvenil respalda-se na tentativa de se formar leitores responsivos, críticos, pensantes e transformadores do meio social em que convivem, pois o que se constata é que há um tipo de apatia nos alunos da turma da intervenção, pois veem certos assuntos com desdém ou com distanciamento, como se não fizessem parte do processo e dos possíveis desdobramentos políticos e sociais. Dessa forma, o funk nos permite estimular o embate de ideias, bem como refletir acerca de novas nuances estéticas, tendo em vista que tal gênero é bastante polêmico e por muitas vezes criticado negativamente pela comunidade escolar, seja pelos discentes, pelos seus pais ou até mesmo pelos docentes. Nessa perspectiva, talvez, nossos alunos ainda não estejam tão acostumados a ler e a produzir, pois eles compreendem várias temáticas e com algumas até se identificam, mas ainda não apresentam um olhar crítico sobre os porquês dos encadeamentos e dos

\footnotetext{
${ }^{3}$ O presente artigo é resultado de investigação e intervenção no âmbito do Mestrado Profissional em Letras (Profletras) na unidade associada da UFRN em Natal.
} 
desdobramentos das ideias no que tange à sua produção. Com isso, o seu olhar, como autores, ainda não os faz "enxergar" a si próprios como reais participantes do que escrevem.

O autor é profundamente ativo, mas o seu ativismo tem um caráter dialógico especial. Uma coisa é o ativismo (aktívnost) em relação a um objeto morto, a um material mudo, que se pode modelar e formar ao bel-prazer; outra coisa é o ativismo em relação à consciência viva e isônoma do outro. Esse ativismo que interroga, provoca responde, concorda, discorda, etc., ou seja, esse ativismo dialógico não é menos ativo que conclui, coisifica, explica por via causal, torna inanimada e abafa a voz do outro com argumentos desprovidos de sentido (BAKHTIN, 2011, p. 339, grifo nosso).

Alguns alunos(as) adolescentes acreditam ter o seu próprio mundo e que sua maneira de se comunicar seria só dele, não advindo de lugar algum, tal visão de singularidade de voz se configuraria em engano, pois o seu espaço e o seu mundo já estão postos, conforme afirma Geraldi (2013): “o mundo não nos é dado, mas construído" e para que seja construído ninguém parte de nada; há uma natureza dada na qual operamos todos nós (nunca sós), sendo necessário que pensemos que outros seres nesse ambiente compartilham sua vida conosco. Ou seja, a chave para o autoconhecimento virá a partir da figura do outro, invariavelmente.

\title{
1 Referencial teórico
}

\begin{abstract}
Os gêneros têm um significado particularmente importante. Ao longo de séculos de sua vida os gêneros (da literatura e do discurso) acumulam formas de visão e assimilação de determinados aspectos do mundo. Para o escritor-artesão, os gêneros servem como chavão externo, já o grande artista desperta neles as potencialidades de sentido jacentes. Shakespeare usou e inseriu em suas obras os imensos tesouros dos sentidos potenciais que em sua época não puderam ser descobertos e conscientizados em toda a sua plenitude. O próprio autor e os seus contemporâneos veem, conscientizam e avaliam antes de tudo aquilo que está mais próximo do seu dia de hoje. $\mathrm{O}$ autor é um prisioneiro de sua época, de sua atualidade. Os tempos posteriores o libertam dessa prisão, e os estudos literários têm a incumbência de ajudá-lo nessa libertação (BAKHTIN, 2011, p. 364).
\end{abstract}

Pensando na leitura e na produção textual com base nos gêneros do discurso, na relação dialógica da linguagem e na sua função social, optou-se, neste trabalho, por eleger como referencial teórico as concepções do Círculo de Bakhtin ${ }^{4}$, incentivador de discussões teóricas e pedagógicas na área do ensino de línguas. Na busca por base teórica para o trabalho que lida diretamente com a linguagem, o discurso em sala de aula, os estudos fulcrados em Bakhtin servirão de base e sustentáculo na medida em que a interação entre indivíduos (seja consigo

\footnotetext{
${ }^{4}$ Denomina-se Círculo de Bakhtin um grupo de estudiosos, pesquisadores e teóricos de diferentes áreas do conhecimento, tais como: Volochinov, Medvediev, Yudina, Kagan, entre outros.
} 
mesmo, seja com o outro) necessita de um elemento mediador desse estudo, tendo em vista a amplitude e o alcance da teoria bakhtiniana desenvolvidas.

\section{O enunciado concreto}

O enunciado é a réplica de um diálogo, visto que ao se produzir um enunciado se participa de um diálogo com outros discursos, estando acabado quando permite uma resposta de outro.

Tudo o que dizemos, cantamos ou escrevemos/digitamos, tudo o que enunciamos, dáse concretamente na forma de enunciados ou textos. E todo enunciado articula-se em uma forma relativamente estável de enunciar, que é o gênero. Um enunciado serve para expressar, por meio da língua/linguagem, uma significação, uma apreciação a respeito do mundo, das coisas, dos outros e de outros ditos (ROJO, 2015, p. 28).

O enunciado não existe fora das relações dialógicas, nele estão presentes a repetição e as lembranças de outros enunciados que ele conta, refuta, confirma, completa, pressupõe e, assim por diante, ocupando sempre uma posição na esfera de comunicação sobre um determinado problema. A partir dos enunciados, podem-se compreender as relações dialógicas postas que se dão sempre entre enunciados plenos, concretos e historicamente situados.

\section{Gênero discursivo}

A atividade humana está ligada inexoravelmente à linguagem, elemento imprescindível para que as interações aconteçam. Dessarte, a linguagem aparece multifacetada para atender aos diferentes campos que a atividade humana exige. Segundo Bakhtin (2011), o emprego da língua se dá por meio de enunciados orais ou escritos, concretos e únicos, proferidos pelos integrantes de determinado campo da atividade humana. Os enunciados, por sua vez, são o dizer ou o querer dizer do indivíduo, são o reflexo concretizado das condições de determinado campo em que o conteúdo temático, o estilo e a construção composicional se sobressaem, ligam-se e são determinados, a depender da área de atuação. Esses três elementos fazem parte do enunciado e cada enunciado é particular, é individual, mas cada campo de utilização da língua elabora os seus tipos relativamente estáveis de enunciados, os quais denominamos gêneros do discurso (BAKHTIN, 2011).

Ao se trabalhar com gêneros, mediante a proposta bakhtiniana, não se deveria ter como prioridade a classificação de tipos e a análise de oração gramatical em que não se obtêm 
posicionamentos de fato, mas priorizar o dialogismo que permeia o processo interativo, pois, como afirma Casado Alves (2014, p. 26), o gênero pode, sim, ser ensinado:

\begin{abstract}
Assumimos [...] que o gênero discursivo, a despeito de algumas discussões, estéreis a nosso ver, de que o gênero não se ensina, uma vez que não há como replicar as práticas de linguagem diversas e singulares nas quais ele mesmo seria produzido (algo que nos parece também acontecer com o texto de tal forma que ele também não poderia ser nosso instrumento/objeto de ensino), pode orientar o ensino de leitura e de escrita em sala de aula se se considerar com Rojo (2008) uma orientação bakhtiniana para além da forma do texto, dos elementos linguísticos e do tratamento do contexto.
\end{abstract}

O ensino dos gêneros não é uma prática atual. Como bem enfatiza Bakhtin (2011), a língua passa a integrar a vida a partir dos enunciados concretos (que realizam); é igualmente via os enunciados concretos que a vida entra na língua. Para que se compreenda o fenômeno da linguagem, é necessário que os indivíduos se situem na mesma prática social envolvida, ou seja, que os interlocutores compartilhem da mesma comunidade linguístico-discursiva, que estejam integrados à mesma unicidade da situação social imediata e, nesse caso, a linguagem consiste no suporte para o que se chama de processo de interação. Segundo Geraldi (2015, p. 35),

Focalizar a linguagem a partir do processo interativo e com esse olhar pensar o processo educacional - e escolar, de forma específica - exige instaurar a este sobre a singularidade dos sujeitos em contínua constituição e sobre a precariedade da própria temporalidade que o específico do momento implica. Trata-se de erigir a disponibilidade estrutural para a mudança em inspiração, ao contrário de tomar a estrutura como objeto a ser apreendido e fixado. Consequentemente, há que se destruir fronteiras entre sistemático/assistemático; local/universal; regra/exceção; correto/incorreto e outras dicotomias que vão além do linguístico mas que nele significam. A manutenção destas dicotomias implica alijar da escola o próprio processo constitutivo de sujeitos e da linguagem, vital, momentâneo e próprio com que de fato cada indivíduo assume sua condição de sujeito. O sujeito de discurso sempre tem com as condições de emergência de sua fala uma relação de pertinência.

A variedade dos gêneros discursivos é infinita, uma vez que o surgimento de novos gêneros cresce a cada época para atender as mais diversas necessidades e demandas por seu caráter multiforme, assim como a atividade humana. É enorme a heterogeneidade dos gêneros, sejam orais, sejam escritos, dada a infinidade de gêneros existentes.

Bakhtin (2011) mostra que os enunciados e seus respectivos gêneros discursivos são correias de transmissão entre a história da sociedade e a história da linguagem, reiterando a ideia de que os gêneros são tipos relativamente estáveis de enunciados; o termo relativamente é alusivo à historicidade do gênero, à sua permanente mudança, de onde se deduz que não se poderia usar o conceito de gênero de uma forma engessada, dotada de normatividade, dada a permanente mutação dos gêneros do discurso em diferentes espaços sociais e em diferentes épocas. A título de exemplo, os gêneros representativos da esfera jornalística (reportagem, 
notícia) do início do século XX eram bem diferentes no que se refere ao seu conteúdo temático, à construção composicional e ao estilo em relação aos atuais, muito embora o gênero, para aquele teórico, seja o mesmo.

Em cada época de evolução da linguagem literária, o tom é dado por determinados gêneros do discurso, e não só secundários (literários, publicísticos, científicos) mas também primários (determinados tipos de diálogo oral - de salão íntimo, de círculo familiar-cotidiano, sociopolítico, filosófico, etc.) (BAKHTIN, 2011, p. 268).

Ou seja, cada gênero vive em constante mudança à medida que as diversas esferas da atividade humana vão se transformando e ficando mais complexas e exigentes, o que proporciona o desaparecimento ou o aparecimento de determinado gênero: a carta atualmente aparece em certo desuso nos lugares em que se dispõe da internet, dando lugar ao e-mail.

\subsection{Gênero discursivo "funk" em perspectiva dialógica}

Quanto à forma de composição, pode-se afirmar que o tema em estudo diz respeito ao gênero multimodal musicalmente classificado como gênero canção funk e, textualmente falando, como letra de canção, estando envolvidos os elementos acabamento musical harmônico, melódico e rítmico. O funk, entendido como uma modalidade do gênero canção (um gênero híbrido de caráter intersemiótico), aproxima-se do poema, por ser dotado de versos, com métrica (adequada ao ritmo) e rima.

Todo dizer, seja oral, seja escrito, está sistematizado, ou seja, configurado em um gênero discursivo. Dessa forma, os gêneros organizam a nossa intenção comunicativa que se concretiza por meio dos enunciados.

Nesse processo de interação, o enunciador leva em consideração o discurso do outro que, por sua vez, está presente no seu, pois todo discurso é, inevitavelmente, afetado pelo discurso alheio. Para tanto, instauram-se as relações dialógicas, ou seja, as relações de sentido que são mantidas e nutridas entre dois enunciados, as quais constituem o princípio unificador da obra de Bakhtin e de seu Círculo, examinado sob diferentes ângulos e manifestações. O dialogismo está difundido na concepção bakhtiniana de linguagem e constitui, também, sua antropologia filosófica: a língua em sua totalidade é dialógica em todos os enunciados no processo de interação, independentemente de sua dimensão.

Logo, o dialogismo, postulado pelo Círculo de Bakhtin, poderia ser ilustrado como uma moeda que comporta duas faces: vem de alguém que se dirige a alguém. Essa moeda, por sua vez, vai passando, de mão em mão, assim como as vozes que circulam. Esse fluxo 
discursivo, dadas as esferas e as situações comunicativas, vai se sedimentando, moldando-se em gêneros que servem para atender a tais situações e a necessidades que se refletirão no poder dizer, no saber dizer, nas formas de dizer.

Essa relativa estabilidade dos gêneros, como já mencionado, não implica dizer que eles sejam imutáveis, considerando a sua ampla concepção, o seu estilo próprio e a possibilidade real de que a criação de um estilo individual se concretize. Nesse sentido, Bakhtin aponta duas forças da linguagem que coexistem: as forças centrípetas e centrífugas. As centrípetas (forças dominantes) são responsáveis por estabilizar os gêneros, tornando-os homogêneos; já as centrífugas são justamente aquelas que desestabilizam os gêneros, tornando-os heterogêneos, misturados, hibridizados. Essas formas se opõem e marcam de maneira indelével os gêneros. $\mathrm{O}$ funk, enquanto gênero proposto para estudo em sala de aula, foi um exemplo do embate de forças (ideias), uma vez que o pensamento dominante, na turma, era de repulsa ao estudo em sala, tendo em vista o preconceito e a ideologia trazida do seu convívio familiar ou de amizades, por exemplo.

Os gêneros discursivos, tipos relativamente estáveis do discurso, são o fruto das esferas da atividade humana (caracterizadas como esferas da comunicação verbal) que merecem atenção, tendo em vista a relação entre a linguagem e a maneira como uma sociedade se organiza. O contexto sócio-histórico, o tempo e o espaço em que se inserem representam os valores e as percepções de mundo. Essa representação de valores, de visão, de percepção e de ideologias, dada a força predominante da língua/linguagem, fomentam as relações dialógicas e, ao mesmo tempo, possibilitam o embate entre as forças centrípetas e centrífugas. Cada enunciação concreta do sujeito do discurso é um ponto de articulação tanto das forças centrípetas quanto das centrífugas (BAKHTIN, 2015). Sendo assim, torna-se imprescindível, para uma melhor compreensão dos gêneros, que se estudem as possíveis relações entre as diferentes esferas da comunicação verbal em seu contexto social, histórico e temporal (cronotopia).

A cada época, vários gêneros surgem a depender da necessidade comunicativa imposta e da "ideologia cotidiana", o que, para Volochínov (2013, p. 151), é definida como

[...] todo conjunto de sensações cotidianas - que refletem e refratam a realidade social objetiva - e as expressões exteriores imediatamente a elas ligadas. A ideologia cotidiana dá significado a cada ato nosso, a cada ação nossa e a cada um de nossos estados "conscientes". Do oceano instável e mutável da ideologia afloram, nascem gradualmente as inumeráveis ilhas e continentes e os sistemas ideológicos: a ciência, a arte, a filosofia, as teorias políticas. 
Em um contexto embebido de uma ideologia cotidiana, surge o funk, gênero musical vindo dos EUA, que tem sido bastante divulgado no Brasil por trazer uma alta carga de identificação por parte de determinados grupos sociais. A partir desse gênero, eles encontram a reverberação de suas vozes (não dominantes) por meio dos discursos proferidos no cotidiano, como a realidade das comunidades, o humor, a questão socioeconômica, sendo esta última a temática mais presente em suas letras.

Os gêneros podem ser considerados instrumentos facilitadores da comunicação e da aprendizagem. Nessa esteira, o funk é um heterodiscurso dialogizado (BAKHTIN, 2015) e, por isso, passou e ainda passa pelo que se chama de preconceito linguístico e social. Isso se dá porque seu conteúdo envolve uma gama de temas que faz parte do cotidiano das classes ditas mais baixas na escala social: traz não só a sua riqueza de valores e de esperanças, mas também uma carga bastante marcante de mazelas que são expressas em suas letras, como a violência, o valor material dos bens de consumo que se traduzem em poder, a desvalorização da figura feminina e a erotização exacerbada, por muitas vezes. Esses fatores geram uma visão negativa acerca do gênero, mas compreendê-lo se faz necessário à medida que seu alcance se estendeu para boa parte do território nacional, para quase todas as classes e idades, sobretudo os adolescentes.

A filosofia da linguagem, a linguística e a estilística, nascidas e em formação no leito das tendências centralizantes da vida da linguagem, ignoravam esse heterodiscurso dialogizado, que materializava as forças centrífugas da língua. Por isso não lhes podia ser acessível a dialogicidade da linguagem, condicionada pela luta entre pontos de vista sociolinguísticos, e não pela luta intralinguística de vontades individuais ou por ligações lógicas (BAKHTIN, 2015, p. 43).

Designar o gênero não é o mais importante e não precisa de um conhecimento técnico específico para o seu (re)conhecimento. Para Rojo (2015, p. 27), "os gêneros são radicalmente uma entidade da vida [...] os gêneros não são abstrações teóricas, são universais concretos que circulam na vida real". Ou seja:

Os gêneros são constituídos historicamente, usados e experimentados socialmente, tendo existência e força na vida social, embora só se materializem em textos e enunciados e não como gêneros em si. [...] os gêneros são formas de dizer, de enunciar, de discursar tramadas pela história de uma sociedade, de uma cultura e que nela circulam nos saberes das pessoas - um universal -, mas que só aparecem concretamente na forma de textos orais, escritos ou multimodais, isto é, aqueles que misturam várias modalidades de língua/linguagem (verbal, oral ou escrita; imagem, estática; ou em movimento, sons musicais (ROJO, 2015, p. 28). 
Para a teoria bakhtiniana, o sujeito não é assujeitado, ou seja, submisso às estruturas sociais, nem é uma subjetividade autônoma em relação à sociedade. O princípio geral do agir é que o sujeito age em relação aos outros, o indivíduo se constitui em relação ao outro, significando que o dialogismo é o princípio de constituição do indivíduo e o seu princípio de ação. A consciência constrói-se na comunicação social (sociedade, história), por isso, os conteúdos que a formam e a manifestam são semióticos. Segundo Rojo (2012, p. 14, grifo do autor), "Vivemos, já pelo menos desde o início do século XX (senão desse sempre), em sociedades de híbridos impuros, fronteiriços”. Em relação à diversidade, a autora acrescenta:

\begin{abstract}
No caso brasileiro, em nossas salas de aula, essa mistura de culturas, raças e cores não constitui constatação tão nova, embora passe o tempo todo quase totalmente despercebido ou propositadamente ignorada. Quais serão os Iaiá/Rasga o coração que nossos alunos - rappers, funkeiros, pagodeiros, sertanejos - incluem em suas leituras “canônicas" de José de Alencar, ele mesmo um folhetinista? (ROJO, 2012, p. 15).
\end{abstract}

Para ela, a produção cultural está cada vez mais híbrida, o que impede a manutenção das dicotomias.

Como bem mostra García Canclini (2008[1989]), esses pares antitéticos - cultura erudita/popular, central/marginal, canônica/de massa - já não se sustentam mais faz muito, nem aqui, nem acolá... Os híbridos, as mestiçagens, as misturas reinam cada vez mais soberanas. Para o autor, a produção cultural atual se caracteriza por um processo de desterritorialização, de descoleção e de hibridação que permite que cada pessoa possa fazer "sua própria coleção", sobretudo a partir das novas tecnologias (ROJO, 2012, p. 16).

A apreensão do mundo é sempre situada historicamente, porque o sujeito está sempre em relação com outro(s); vai constituindo-se discursivamente, apreendendo as vozes sociais que constituem a realidade em que está imerso e, ao mesmo tempo, suas inter-relações dialógicas. O sujeito não absorve apenas uma voz social mas várias que estão em relações diversas entre si, já que a realidade é heterogênea, fazendo com que o seu mundo interior seja constituído de diferentes vozes em relação à concordância e à discordância. Dessa forma, o seu mundo exterior nunca está acabado, fechado, vive em constante vir a ser.

\title{
4 Leitura como prática social e atividade responsiva
}

Ao se falar em projeto que envolva leitura, algumas questões emergem: o que é leitura e qual é a sua importância? Neste estudo, não se pretende dizer tudo acerca de um tema que (felizmente) não se esgota, e sim abordar aspectos que envolvem e tornam a leitura uma 
condição essencial no que diz respeito a aprender, a compreender e, principalmente, à formação de cidadãos plenos de responsividade. Para um melhor embasamento, teóricos como Bakhtin (2011), Paulo Freire (2011), Geraldi (1997), entre outros, farão parte deste trabalho, dada a relevância das contribuições em relação ao tema proposto.

A leitura ainda é vista, muitas vezes, em âmbito escolar, como um ato individual do leitor para que se aprenda conteúdos, sem que se conclua que a leitura é um bem social que o aluno agrega, antes de tudo. Na escola, ainda persiste a ideia do que seja uma boa e uma má leitura. Nesse sentido, a leitura dos clássicos, considerada como literatura de prestígio, por exemplo, sempre foi "empurrada de goela a baixo" pelos programas conteudistas das grades curriculares sem um trabalho que justifique e responda, de maneira clara, sobre os porquês de aquela obra ser adotada para os alunos (vão ler porque está no programa). Dessa forma, a escolha se torna mais fácil e menos questionada. Realidades como essas lembram a "visão bancária da educação", tão comentada e criticada por Freire:

Para o "educador-bancário", na sua antidialogicidade, a pergunta, obviamente, não é a propósito do conteúdo do diálogo, que para ele não existe, mas a respeito do programa sobre o qual dissertará a seus alunos. E a esta pergunta responderá ele mesmo, organizando seu programa (FREIRE, 1987, p. 58).

Para Silva (1997), os clássicos, por exemplo, por terem já sido consagrados, trazem consigo o peso da autoridade e a certeza da impunidade. Estão acima de qualquer suspeita. Não podem ser rejeitados publicamente. Nesse sentido, Benevides (2008, p. 89) diz que

\footnotetext{
A abundância de livros, a escolha de autores (na maioria os clássicos), os lugares apropriados para o ato de ler e para os livros propriamente ditos geralmente fazem parte de um discurso e de uma prática elitizados sobre a leitura. Esse discurso elitizado que predomina nas vozes do estrangeiro, dos visitantes europeus (e mais atualmente, dos americanos) com modos culturais distantes dos da realidade do Brasil, por exemplo.
}

Obviamente o aluno precisa ler os clássicos ou as obras socialmente valorizadas, pela importância do contexto histórico e social que determinadas obras trazem e que ajudam na compreensão do que se tinha e do que se tem hoje em termos políticos e sociais, visto que tais livros não são considerados clássicos sem motivo algum. Contudo, outras leituras, aliás, qualquer leitura pode ser válida, tudo depende da perspectiva que determinado texto vai trazer para cada leitor, que também é único. Surge, assim, outra dificuldade para o professor, que é 
propor leituras que agradem à boa parte dos alunos, ao menos. Quanto à discussão sobre a unicidade do leitor e o sentido do texto que se completa no leitor, Geraldi (1997, p. 91) afirma:

\begin{abstract}
O autor, instância discursiva de que emana o texto, se mostra e se dilui nas leituras de seu texto: deu-lhe uma significação, imaginou os seus interlocutores, mas não domina sozinho o processo de leitura de seu leitor, pois este, por sua vez, reconstrói o texto na sua leitura, atribuindo-lhe a sua (do leitor) significação.
\end{abstract}

É necessário que sejam também oferecidos textos que consigam se aproximar mais da área de interesse dos alunos ou de sua realidade para fins de reflexão, já que o leitor não é passivo, procura significado do que lê naquele texto que, para outro leitor, dada as situações dialógicas e a inexistência de neutralidade de sentido, adquirirá, inexoravelmente, outras significações. Em suma, como Freire (2011, p.10) afirma: "a leitura de mundo precede a leitura da palavra, daí que a posterior leitura desta não possa prescindir da continuidade da leitura daquele". A assertiva freireana parece óbvia, mas a sua vivência concreta por parte do que se tem em termos de leitura não segue na mesma toada: os alunos não costumam se identificar com os textos oferecidos na escola, costumam achar que servem apenas para fazer as tais atividades que o professor mandou, em outras palavras, "cumprir tabela em português".

Por sua vez, o professor também precisa entender que não participa como agente principal do processo de leitura de seu aluno, seu papel é outro, o de mediador, visto que o mesmo texto por ele lido anteriormente e levado para a sala já adquiriu sua própria significação e importância, uma das leituras possíveis (para o professor-leitor). Por isso, vale a reflexão sobre o que é oferecido em termos de leitura que traz leitura do mundo do seu aluno.

Cabe ainda ressaltar que tal atividade não é nada fácil, dadas as dificuldades enfrentadas pelo professor, como a falta de autonomia na escolha de conteúdos que são exigidos pela instituição de ensino em busca do cumprimento do programa, mormente os diversos posicionamentos que o leitor apresenta diante de cada tipo de leitura.

Existe, e não se pode olvidar, o que se chama de leitura de mundo, que é o resultado da tríade: aquilo que se vê, aquilo que se lê e aquilo que se vive. A leitura não é ato pacífico ou passivo, requer a participação efetiva e comprometida do leitor. Para Almeida (2010, p. 44):

Ler é, acima de tudo, ação cidadã. Quando o indivíduo apreende o processo de leitura, ele pode desencadear leituras do mundo, seja pela sua experiência, seja por sua percepção ou por sua formação. Ler o mundo é compará-lo, desconstruí-lo e reinventá-lo a seu modo.

Sob essa ótica, o ato de ler constitui-se em um permanente diálogo para a construção de um sujeito autônomo e responsivo, pois é no momento da interação entre leitor e texto que 
o seu sentido se perfaz e se efetiva, em outras palavras, pode-se dizer que ler é também uma negociação entre o texto e o leitor, de forma que este completa e dá sentido àquele. Ler é significar e dar significado.

\section{Protótipo de ensino}

Antes de prosseguir, fez-se necessário discutir o que significa o termo protótipo até chegar à ideia do que seria o protótipo de ensino trabalhado nesta pesquisa. Segundo o dicionário Houaiss (2004, p. 604), o termo corresponde a: "s.m.1. modelo criado para servir de teste 2. modelo, padrão". Ou seja, em relação a protótipos, entende-se que se trata de um modelo não acabado, dependente ainda de testes e sujeito a aprimoramentos.

Protótipos de ensino, segundo Rojo (2013, p.19, grifo do autora),

São espécies de sequências didáticas para os multiletramentos e novos letramentos, mas com uma arquitetônica vazada e não preenchidas completamente com atividades planejadas previamente pelo autor, sem conhecer o contexto de ensino. São sempre acompanhadas de tutoriais com explicações sobre os princípios de funcionamento de ferramentas e textos em gêneros digitais, para que sirvam como elementos catalisadores do processo de autoria docente e discente (por isso, protótipos).

O protótipo de ensino proposto constituiu-se numa sequência de atividades planejadas com base nas observações feitas em sala de aula e que possui como principal característica a flexibilidade e a possibilidade de ajustes no processo, tendo, portanto, a capacidade de ser adaptável em qualquer situação. Assim,

Um protótipo de ensino seria um "esqueleto" de SD a ser "encarnado" ou preenchido pelo professor, por exemplo, um modelo didático digital de um gênero ou conjunto de gêneros, sem seus acervos ou bancos de textos, ou apenas com acervos e bancos que funcionassem como exemplos e pudessem ser substituídos no produto final (ROJO, 2013, p. 26, grifo do autor).

Quando Rojo faz uso do termo “esqueleto", refere-se ao modelo (ou a uma parte dele) do gênero que está sendo trabalhado, ao funcionamento e às características, de acordo com a teoria adotada pelo profissional que está aplicando o protótipo de ensino. Alie-se a isso o que se pretende no quesito ensino-aprendizagem e nos objetivos pretendidos no protótipo de ensino.

Esse esqueleto, na medida em que tem uma arquitetônica parcialmente vazada e dialógica, sustenta ou suporta uma variedade de funcionalidades inteligentes - de objetos digitais (textos, vídeos, animações, playlists, podcasts etc.) e de ferramentas (de produção de texto, áudio, vídeo, design gráfico, busca e curadoria, agregação de conteúdo, publicação de conteúdo etc.), à escolha dos(as) professores(as) (ROJO, 2013, p. 23, grifo do autor). 
Os protótipos de ensino, em última análise, são suportes ecléticos, democráticos, adaptáveis a qualquer conteúdo, tornando-se uma ferramenta bastante útil ao professor. Mais adiante será descrita a Escola Estadual, na qual o protótipo de ensino foi aplicado com os alunos do $9^{\circ} \mathrm{A}$.

\subsection{Aplicação do protótipo}

As atividades propostas envolveram a escrita e a oralidade e resultaram das discussões de sala de aula, a partir da exposição do posicionamento de cada aluno da turma. Nesse processo, várias foram as atividades que se apresentaram em forma de enquetes, de escuta e de análise de músicas de funk, principalmente, da linguagem empregada e de que maneira esta dialoga com cada um dos alunos e, por fim, a reflexão dos temas propostos em sala por meio de uma roda de conversa.

Resumidamente, demonstraremos o recorte de duas questões, da primeira e da última aula, com as respectivas respostas que deram suporte à análise do sujeito leitor a partir da leitura e da discussão de cada texto proposto em sala. Cada recorte constará de questionamentos feitos pelo professor mediador e respostas dos alunos.

O recorte abaixo remete ao primeiro dia da aplicação do protótipo de ensino:

"Você acredita que o gênero funk pode ser um tema trabalhado em sala de aula? Justifique".

Com isso, apresentamos algumas das respostas/vozes dos alunos(as), ressaltando que as transcrições serão literais em função do que o aluno preencheu em seu questionário, incluindo possíveis “inadequações” linguístico/discursivas.

\footnotetext{
Aluno 1: Não, porque não acho que seja um tema que possua temas do tipo educacional.

Aluno 2: Não, porque as letras são muito imorais, não acho que seja um assunto pra ser discutido em sala de aula.

Aluno 4: Não porque é um estilo musical que não vai agradar todos, nem todo mundo gosta.

Aluno 6: Sim, porque as pessoas precisam ter a mente aberta para outros gêneros musicais.

Aluno 11: Apesar de não gostar, se usassem o tipo de música com letas mais agradáveis, poderia ser um tema trabalhado.
}

Registramos, nesse sentido, o enunciado oral (as conversas foram gravadas para possíveis transcrições) do Aluno 2 que escreveu de outra maneira, conforme se constata acima, mas afirmou: "Professora, eu odeio o funk porque só fala putaria". Vale salientar que o aluno 
em questão tem por hábito falar palavrões e expressões de baixo calão em plena aula, cotidianamente, não respeitando o ambiente de sala de aula. Tal fato nos chamou a atenção no momento do seu posicionamento, pois apenas reproduz o que vários segmentos da sociedade, incluindo os próprios docentes da própria escola, sempre propagam: a carga sociocultural tão nociva que poderia influenciar negativamente as pessoas adeptas do gênero musical funk. Outro aluno questionou em tom de reclamação: "Professora, a senhora tá querendo que a gente goste de funk, é? Se for, pode desistir!". Ao final, três alunos foram enfáticos: "Funk é lixo!".

Ficou bastante evidente, nessa primeira etapa, a reprodução da carga preconceituosa que envolve o gênero, a partir das vozes implicadas na atividade. $\mathrm{O}$ enunciado produzido nos soou como mais uma provável "reprodução" das vozes de segmentos da sociedade que, mesmo sem conhecer com um pouco mais de propriedade as características do funk, preferiram repudiá-lo prontamente. Quando Bakhtin (2010) afirma que toda palavra se constitui justamente no produto da interação entre falante e ouvinte, as respostas dos alunos(as) não nos causaram surpresa, pois suas vozes pareciam impregnadas das vozes sociais da comunidade em que vivem: família, amigos e o próprio ambiente escolar.

Por fim, o recorte da última intervenção que consistia na apresentação de um seminário e as perguntas se deram após cada apresentação.

Dentre os questionamentos feitos ao final do trabalho, destacamos os dois a seguir, aos quais cada aluno, independentemente de grupo, deveria responder:

1) Qual é a sua opinião sobre o funk? Acredita que pode ser trabalhado em sala de aula?

2) De que maneira a leitura contribuiu na formação da sua opinião?

Transcrevemos a seguir os posicionamentos de alguns alunos armazenados em áudios gravados em sala de aula, cujas argumentações consideramos relevantes como recorte, podendo ilustrar os resultados obtidos em nossa pesquisa. Escolhemos o recorte abaixo, porque o grupo a se apresentar foi justamente aquele que categoricamente afirmou que "funk é lixo!", incluindo o Aluno 2. Segue o diálogo entre a professora pesquisadora e o Grupo 1:

Grupo 1: A gente achou esse o melhor clipe de funk porque abre muito a mente dos jovens sobre o que tá acontecendo hoje no Brasil e é muito importante estudar sobre isso.

Se você acha que o funk é falta de educação e de moral não é bem assim.

Alguns dizem que o funk não presta e até têm razão, a maioria das letras não tem conteúdo.

Professora/mediadora: O que é o funk consciente na opinião do grupo? 
Grupo 1: Funk consciente tem o objetivo de conscientizar as pessoas sobre a situação atual do Brasil como a religião, o preconceito, economia... Eles pegaram um ritmo bastante conhecido pelos jovens e fizeram disso uma ponte.

Professora/mediadora: Então vocês acham que foi positiva a experiência de escolher a letra com a batida do funk para passar a mensagem?

Grupo 1: Foi. Se tivesse feito com outros gêneros não ia 'bater tanto' porque o pessoal não escuta tanto outros gêneros.

Professora/mediadora: Quais os aspectos positivos e negativos do funk?

Grupo 1: A gente não achou muita coisa, conversamos e achamos a nossa opinião mesmo [...] Conversamos e achamos que o funk traz oportunidade pros jovens. Ele ganhou muito dinheiro com aquela música Baile de favela.

[...] E aqui ele veio da pobreza e conseguiu o seu espaço no funk e tá ganhando dinheiro até agora; o MC Guimê também. E também tem a conscientização dos jovens, que é uma exceção, né? Nem todos os funks conscientizam, mas o que a gente tá trabalhando conscientiza muito. Os aspectos negativos do funk que é a apologia às drogas, às armas, tratam a mulher como objeto e não como pessoa. Várias crianças podem escutar esse tipo de música e fazer esse tipo de coisa.

Professora/mediadora: O funk pode ser trabalhado nas escolas?

Grupo 1/Aluno 2: A gente fala que pode, aliás, não só o funk, porque outros gêneros musicais abordam muita cultura. Então é muito bom trabalhar esses gêneros. Sempre mantendo o respeito em sala de aula, palavrões não podem ser falados em respeito ao professor.

Professora/mediadora: Qual foi a importância da leitura para trabalhar esse gênero com o qual vocês não tinham muita intimidade?

Grupo 1: A gente se aprofunda mais no tema, adquire conhecimentos. Além da música a gente ganha a história de vida dos funkeiros, o lado bom também, porque geralmente só vemos o lado ruim. A gente generaliza.

Professora/mediadora: Vocês mudaram um pouco a ideia que vocês tinham do funk depois das leituras?

Grupo 1/Aluno 2: Sim, escutamos não só essa música do MC Garden, mas outras e [...] mas o funk consciente é muito bom, eu aprovei e recomendo pra todo mundo

Nesse recorte, destacamos a postura do grupo em relação ao gênero apresentado no início da aplicação do protótipo e no final de toda essa trajetória, quando, por exemplo, dizem: "Se você acha que o funk é falta de educação e de moral não é bem assim", "Alguns dizem que o funk não presta e até têm razão, a maioria das letras não tem conteúdo". Foi interessante perceber a mudança de uma postura tão radical do grupo perante o gênero estudado inicialmente: o que antes parecia inadmissível para eles, ter o gênero funk como algo a ser estudado e trabalhado na escola, depois das leituras, tornou-se uma atividade possível como outra qualquer do currículo escolar, de acordo com o que foi relatado.

Esses posicionamentos discursivos nos fazem refletir sobre o que Bakhtin diz acerca da relação entre o mundo da cultura e o mundo da vida destacando o conceito de ato ético (OLIVEIRA, 2008), que é resultante de ações realizadas pelos sujeitos, em sua existência concreta, carregado de valores, de avaliações, de posicionamentos. É por meio desse ato que o sujeito se reconhece e também é reconhecido, tendo em vista que tal ato é parte integrante do ser e de suas ações. E a linguagem, ainda na esteira do teórico russo, seria o elemento que enuncia o ato ético, pois a palavra é carregada de valores. Assim, quando os alunos dizem que 
a maioria das letras não teria conteúdo, eles estariam refletindo e refratando os valores que permeiam o seu convívio social.

Quando perguntado se o funk poderia ser trabalhado nas escolas, o aluno 2 respondeu: "A gente fala que pode, aliás não só o funk, porque outros gêneros musicais abordam muita cultura. Então é muito bom trabalhar esses gêneros [...]”. Interessante notar que os alunos que formaram a dupla em questão, quando indagados na primeira intervenção sobre o que achavam do funk, foram alguns dos que falaram que funk era lixo. A mudança daquela postura tão rígida e, consequentemente, do posicionamento meramente repetitivo veio, provavelmente, das contribuições provenientes da leitura e das discussões e reflexões em nossas rodas de conversa. Vejamos, ainda, o que o Aluno 2 disse sobre a importância da leitura para trabalhar esse gênero com o qual não tinha muita intimidade:

A gente se aprofunda mais no tema, adquire conhecimentos. Além da música a gente ganha a história de vida dos funkeiros, o lado bom também, porque geralmente só vemos o lado ruim. A gente generaliza.

O dialogismo, segundo a teoria bakhtiniana, está ligado à condição humana e à heterogeneidade que lhe é peculiar; o pensamento seria como um signo, não estando especificamente no sujeito, mas entre os sujeitos, por isso acreditamos ser esse um fator que explicaria a carga da influência ideológica que atinge e mantém determinado grupo com voz e posicionamento parecidos ou até iguais. Quando um dos alunos admitiu: “A gente generaliza”, verifica-se uma tomada de consciência que também é dialógica, pois quando o sujeito tenta tomar consciência de si, faz isso, de certa forma, tentando se ver com os olhos do outro e esse outro pode ser alguém do seu convívio ou do seu grupo social, o que também poderíamos considerar como consciência de classe, a depender do caso.

\section{Considerações finais}

Neste trabalho elaboramos um protótipo de ensino inspirado em Rojo (2012) e com base no aporte teórico do Círculo de Bakhtin, procurando compreender os aspectos que fazem das vozes dos alunos do $9^{\circ}$ Ano servir de combustível para os mais variados posicionamentos, por meio de enunciados que, segundo nossas análises, mesmo que de forma incipiente e não exaustiva, puderam nos fazer concluir que o gênero funk foi, do início até o fim da intervenção, polêmico e causa das mais diversas reflexões, tendo em vista a tensão entre as vozes envolvidas no processo. 
Foi interessante perceber a carga preconceituosa que envolve o gênero e que independe da formação escolar ou acadêmica; alguns colegas de profissão, inclusive, questionaram se seria válido trabalhar com um gênero tão polêmico, pois alguns acreditavam ser aquele um tema "pobre e baixo" para fins de pesquisa, explicando que a "pobreza" se daria pelo conteúdo a ser trabalhado e se valeria a pena ser levado aos bancos acadêmicos; e "baixo", dado ao teor das letras que envolvem boa parte das músicas do funk.

Desse modo, o nosso objetivo, no sentido de trazer reflexões para dentro da sala foi exitoso, pois a resposta aos comentários que consideramos preconceituosos por parte de algumas pessoas da escola foi ressignificado por meio do discurso de um dos alunos que fez parte de nossa pesquisa ao dizer em sua apresentação: "A gente generaliza". O mesmo aluno também dizia acreditar que o funk poderia ser trabalhado na escola ao fim da intervenção, cabe destacar, como comentamos anteriormente na parte das análises, que essa reflexão adveio de uma das vozes que formavam o coro dominante no ambiente escolar que o funk é lixo. Eis o sujeito social que buscamos (re)conhecer, aquele que, por meio da leitura e da troca de percepções com outro, se constrói e reconstrói, pois o sujeito está em permanente processo de formação e pode, como foi demonstrado, ter uma tomada de consciência através do processo de reconhecimento do outro, fato que ilustra a importância do dialogismo na formação de sujeitos responsivos.

Buscar o embasamento teórico foi extremamente necessário para que pudéssemos compreender de que forma o discurso (que é dialógico) se dá e como aproveitá-lo da melhor maneira para alcançar os objetivos pretendidos na pesquisa. Nesse sentido, Bakhtin foi fundamental em seus ensinamentos sobre a atuação das forças centrípetas e centrífugas, conforme mencionado no corpo de nosso trabalho.

Também se faz necessário destacar o estudo sobre o enunciado que, segundo o Círculo de Bakhtin, não poderia existir fora das relações dialógicas e que envolve os atos de contar, recontar, refutar, aceitar, negar, entre outros.

A leitura foi um fator primordial para que os alunos tivessem um posicionamento mais crítico e uma postura adotada diante de situações na vida real. Os próprios alunos emitiram a sua opinião sobre de que forma a leitura poderia ter influenciado na maneira como cada um compreendia o gênero funk e o resultado no que diz respeito à importância e à dimensão da leitura no processo de formação de cidadãos mais preparados para lidar com os mais variados gêneros e culturas que estão por vir. 
A maior lição extraída com a nossa experiência é a necessidade do aprofundamento nos estudos por parte do profissional da educação. O conhecimento fará com que o professor tenha um olhar mais aberto e ouvidos mais atentos aos diversos posicionamentos que, inexoravelmente, são trazidos para o ambiente escolar. Assim, o dialogismo se perfaz, na troca com o outro, pois aquele outro também me constitui.

\section{Referências}

BAKHTIN, Mikhail. (VOLOCHINOV). Marxismo e filosofia da linguagem. Problemas Fundamentais do Método Sociológico na Ciência da Linguagem. 14. ed. São Paulo: Hucitec, 2010.

Estética da criação verbal. 6. ed. São Paulo: Martins Fontes, 2011.

. Teoria do romance I: a estilística. 1. ed. São Paulo: Editora 34, 2015.

BENEVIDES, Araceli Sobreira. A leitura como prática dialógica. In: ZOZZOLI, Rita Maria Diniz; OLIVEIRA, Maria Bernadete de (Org.). Leitura, escrita e ensino. Maceió: EDUFAL, 2008.

BRAIT, Beth. Bakhtin: conceitos-chave. 5. ed. e 1. reimp. São Paulo: Contexto, 2013.

CASADO ALVES, Maria da Penha; CAMPOS, Sulemi Fabiano; RODRIGUES, Maria das Graças Soares. (Org.). Ensino de língua portuguesa: gêneros, textos, leitura e gramática. Natal: EDUFRN, 2014.

FARACO, Carlos Alberto. Linguagem \& diálogo: as ideias linguísticas do círculo de Bakhtin, 2009.

FIORIN, José Luiz. Introdução ao pensamento de Bakhtin. São Paulo: Ática, 2008.

FREIRE, Paulo. Pedagogia do oprimido. 17. ed. Rio de Janeiro: Paz e Terra, 1987.

FREIRE, Paulo. A importância do ato de ler: em três artigos que se completam. 51. ed. São Paulo: Cortez, 2011.

GERALDI, J. W. Introdução: o mundo não nos é dado, mas construído. In: VOLOCHÍNOV, V. N. A construção da enunciação e outros ensaios. São Carlos: Pedro \& João, 2013.

GERALDI, João Wanderley. (Org.). O texto na sala de aula. São Paulo: Ática, 1997.

GERALDI, João Wanderley. A aula como acontecimento. São Carlos: Pedro \& João, 2015.

ROJO, Roxane (Org.). A prática de linguagem em sala de aula: praticando os PCN. São Paulo: Mercado das Letras, 2000. 
Materiais didáticos no ensino de línguas. In: MOITA-LOPES, Luiz Paulo (Org.). Linguística aplicada na modernidade recente. São Paulo: Parábola, 2013.

Pedagogia dos multiletramentos: diversidade cultural e de linguagens na escola. In: ROJO, Roxanne; MOURA, Eduardo (Org.). Multiletramentos na escola. São Paulo: Parábola, 2013.

; BARBOSA, Jacqueline P. Hipermodernidade, multiletramentos e gêneros discursivos. 1. ed. São Paulo: Parábola, 2015.

Recebido em 08 de outubro de 2018. Aprovado em 23 de outubro de 2018. 